\title{
STATISTICAL INVESTIGATION OF THE IMPACT OF TIMING OF MARRIAGE ON MARITAL STABILITY OF FEMALE NIGERIANS
}

\author{
D. B, ADEKANMBI, E. I, ENANG, K. O, OBISESAN AND O. R. ONIYIDE
}

(Received 5 July 2009; Revision Accepted 30, October 2009)

\begin{abstract}
This study is a cross-cultural investigation of the impact of Nigerian women's timing of marriage on their marital stability. Gross nuptiality tables and multiple decrement nuptiality tables are constructed based on census data, to examine the regional variations in the nuptiality patterns of Nigerian women across the six geo-political zones in the country. Methodological aspects of the model used in constructing the multiple decrement nuptiality was based on the assumption that re-entrants into marital union is not allowed. The results indicate that girl-child marriage and later-marriage increase the risk of marital dissolution. Various recommendations for policy interventions aimed at improving the marital stability of Nigerian women are stated.
\end{abstract}

KEYWORDS: Marital disruption, Gross nuptiality table, Multiple decrement table, Girl-child marriage, Nuptiality pattern.

\section{INTRODUCTION}

The age and rates of marriage formation, and its disruption are directly related to change in population composition, and the effective length of reproductive periods. There is therefore a necessity to examine the trends in marriage patterns and their changes for the female population in Nigeria. Marriage is universal and is the main social arrangement within which cohabitation and childbearing are encouraged by most society, (Cochrane et al, 1990; Jain, 1969). The universality of marriage in Nigeria is probably a reflection of the social and economic security marriage is perceived to provide. Marriage is generally deemed to mark the individuals' entry into reproductive activities, (National Population Commission, 1998). Formal education has a great influence on age-at-first-marriage and fertility, (Omu et al, 1986, Aborampah, 1987). Dissolution of marital unions exerts a negative influence on the reproductive scenario of married population, (Schoen et al, 1974). Separation, divorce and widowhood represent withdrawals from the married population, which tend to diminish the population to which births are likely to occur, and thereby change the structure, needs and functions of households. (Naushin et al, 1975). One of the most important demographic variables is marital status. Rate of marital dissolution when combined with age-at-first-marriage provides a means of investigating the extent to which timing of marriage is conducive to females' marital stability.

Nuptiality study deals with the frequency of marriages; with the characteristics of persons, united in marriage; and the dissolution of such unions, (Shryock et al, 1976). It is the rate of marriage formation and its dissolution among a population. Nuptiality patterns of women have rarely interested most researchers in developing countries due to lack of data on the subject, (Omideyi, 1986). Nevertheless some researchers in this field have made contributions on this subject, (Mertens, 1965; Naushin et al, 1975; Olusanya, 1982; Hajnal, 1953; Islam et al, 1998; Ephraim, 1999).

This study has its objectives in investigating the regional variations in nuptiality pattern, and in examining the influence of age-at-marriage on the marital stability of women across the social-cultural regions in Nigeria. The demographic tools employed for these purpose are:

(i) Gross nuptiality table, to describe the incidence of marriage among single female population.

(ii) Multiple decrement nuptiality tables, to determine the inter-regional differences in marital stability of married female population.

\section{DATA}

The data for this study are extracted from the 1991 population census conducted by the National Population Commission, Nigeria. The data are on marital status of female populations. The twelve states used in this study were selected from the six geopolitical zones, with two states from each zone. Cluster random sampling technique was employed in the selection of the states for this study. It is proposed that the two states selected from each zone reflect the nuptiality pattern of the region.

The selected states are Bauchi and Yobe from Northeast, Kano and Sokoto from Northwest, Benue and Niger states from Northcentral. From Southeast zone, Anambra and Imo States, Osun and Ondo states from Southwest, and Akwa-lbom and Edo from South-south zone.

\section{SOCIO-CULTURAL CONTEXT OF MARRIAGE IN NIGERIA}

In all the six geo-political zones in Nigeria, the predominant religion and cultural practices of the people in the region have great implications on the nuptiality

D. B. Adekanmbi, Department of Pure and Applied Mathematics, Ladoke Akintola University of Technology, Ogbomoso, Oyo State, Nigeria.

E. I. Enang, Department of Mathematics/Statistics and Computer Science, University of Calabar, Calabar, CrossRiver State, Nigeria.

K. O. Obisesan, Department of Statistics, University of Ibadan, Ibadan, Oyo State, Nigeria.

O. R. Oniyide, Department of Mathematical Sciences, Olabisi Onabanjo University, Ago-Iwoye, Nigeria. 
pattern of female population of the region. The six geopolitical zones in Nigeria are: Northeast, Northwest, North-central, Southeast, Southwest and South-south. All the states in each zone have similarities in terms of religious and cultural practices. Examining the nuptiality patterns of the six zones, therefore, will give a crosscultural differences in the nuptiality pattern of female population in Nigeria.

In Northeast and Northwest, generally Islam is the predominant religion and female child marriage is prevalent in these zones, (Reham, 1984, Isiugo-Abanihe et al, 1993). Early marriage in these zones arose from cultural influences that encourage daughter's marriage after her first menarche. The census data reported a substantial number of female marriages in the ageinterval 10-14 in these northern zones. Female children are rarely given opportunity by their parents to have formal education before they are given in marriage, (Alabi, 1990). This makes school enrolment of young females very low in the northern part of Nigeria. Maternal mortality and the general physiological impairment that tend to accompany early marriage, and a high frequency of child bearing, characterised female marriages in these zones, (Ampofo et al, 1990, Kamara, 1991; Wall, 1998). Islamic religion favours polygamy, therefore many married women in these zones are involved in polygamy. The states in the Northcentral zone exhibit a slight diversity in religious and cultural practices as opposed to the other two northern zones with an indication of slightly lower rates of female child marriages. Marriages in this region are fairly more stable with an evidence of lesser marital instability as compared with the other two northern zones (Solivetti, 1994).

Single females in South-south zone enter into marital unions earlier than their counterparts in Southeast zone, but with slightly higher rate of marital instability. In the Southwest zone mainly populated by the Yorubas, marriage is relatively late due to the high level of education among single female populations, (Weiss et al, 1985). Polygamy is also practiced by the Yorubas, but not as pronounced as in the three northern zones. Later marriage is also common among the Southeastern females, which apart from high female education, may also be ascribable to the culture of high bridewealth that is normally demanded from prospective husbands by brides' family, (Isiugo-Abanihe, 1995). The predominant religion in Southeast and South-south is christianity, which frowns at the culture of polygamy, therefore polygamy is rare in these two southern zones. Marriages in Southeast are relatively most stable, with an evidence of lowest number of marital disruption from the census data.

In all the six zones, it is obvious from the census data that marriage is a universal phenomenon among female populations in Nigeria, with an evidence of very few or no female singles at advanced age.

\section{NUPTIALITY TABLE}

One of the most refined statistical tools used for the purpose of studying the nuptiality pattern is the nuptiality table, (Naushin et al, 1975). Nuptiality table generates the life history of a hypothetical cohort of single persons assumed to have been born at the same time, subjected to cause of decrement due to marriages and deaths occurring at different ages, (Jordan, 1952). When marriage is used as an attrition force of decrement on single population, the resulting table is referred to as Gross nuptiality table.

In this study, age-interval $10-14$ is taken as the minimum age at marriage since the 1991 census reported substantial number of married females in the age group. Marriages over fifty-five are quite insignificant in Nigerian society. In the construction of nuptiality tables for this study, nuptiality span has therefore been taken as 10 to 54 years for single females. Explanation of the various columns of the constructed gross nuptiality tables are given in the footnotes.

\subsection{Estimation of nupitality rates from the census data}

In estimating nuptiality rates for Nigerian females, the proportions single are the basic data needed from the census data. The methodology developed by Mertens (1965), for the estimation of nuptiality rates has been followed in constructing the gross nuptiality tables. The independent rates of nuptiality indicating the probability of first marriage between ages $x$ and $x+n$ for single females are computed from equation (1).

$$
{ }_{5} \mathrm{n}_{\mathrm{X}}=\frac{\mathrm{S}_{\mathrm{X}}^{\prime}-\mathrm{S}_{\mathrm{X}+5}^{\prime}}{\mathrm{S}_{\mathrm{X}}^{\prime}}
$$

where

$\mathrm{S}_{\mathrm{X}}^{\prime}$ : Proportion single females at age $\mathrm{x}$ as given by census data.

$\mathrm{S}_{\mathrm{X}+5}^{\prime}$ : Proprotion single females at age $\mathrm{x}+\mathrm{n}$ from census data.

${ }_{5} \mathrm{n}_{\mathrm{X}}$ : Five year nuptiality rate i.e. the probability that a female single at age $x$ will marry during the next five years.

A prime is used to designate proportions and not to indicate derivative. Once the nuptiality rates have been obtained, the appropriate gross nuptiality tables are not difficult to construct. 
The constructed gross nuptiality tables for female singles in Nigeria based on the 1991 census data are presented in tables 1 to 12 .

GROSS NUPTIALITY TABLES FOR FEMALE SINGLES IN SOUTH-EAST ZONE

Table 1 ANAMBRA

\begin{tabular}{rrrrrrr}
\hline \hline $\mathrm{X}$ & $\mathrm{n}_{\mathrm{x}}$ & \multicolumn{1}{c}{$\mathrm{Sx}$} & \multicolumn{1}{c}{$\mathrm{Hx}$} & \multicolumn{1}{c}{$\mathrm{nLx}$} & \multicolumn{1}{c}{$\mathrm{Tx}$} & \multicolumn{1}{c}{$e_{x}^{0}$} \\
\hline 10 & 0.1460 & 100000 & 14600 & 463500 & 1074446 & 10.7445 \\
15 & 0.4847 & 85400 & 41393 & 323517 & 610946 & 7.1539 \\
20 & 0.4970 & 44007 & 21871 & 165355 & 287430 & 6.5315 \\
25 & 0.6640 & 22135 & 14698 & 73932 & 122075 & 5.5149 \\
30 & 0.6214 & 7437 & 4622 & 25633 & 48143 & 6.4730 \\
35 & 0.4964 & 2816 & 1398 & 10585 & 22510 & 7.9939 \\
40 & 0.3980 & 1418 & 564 & 5679 & 11925 & 8.4093 \\
45 & 0.2226 & 854 & 190 & 3793 & 6246 & 7.3162 \\
50 & 0.5219 & 664 & 346 & 2452 & 2452 & 3.6953 \\
& & 317 & & & &
\end{tabular}

Table 2

IMO

\begin{tabular}{rrrrrrr}
\hline \hline $\mathrm{X}$ & $\mathrm{n}_{\mathrm{x}}$ & \multicolumn{1}{c}{$\mathrm{Sx}$} & $\mathrm{Hx}$ & \multicolumn{1}{c}{$\mathrm{nLx}$} & \multicolumn{1}{c}{$\mathrm{Tx}$} & \multicolumn{1}{c}{$e_{x}^{0}$} \\
\hline 10 & 0.1314 & 100000 & 13140 & 467150 & 1013252 & 10.1325 \\
15 & 0.5592 & 86860 & 48572 & 312870 & 546102 & 6.2872 \\
20 & 0.5449 & 38288 & 20863 & 139282 & 233233 & 6.0916 \\
25 & 0.6955 & 17425 & 12119 & 56827 & 93951 & 5.3918 \\
30 & 0.6118 & 5306 & 3246 & 18414 & 37124 & 6.9968 \\
35 & 0.4160 & 2060 & 857 & 8157 & 18710 & 9.0838 \\
40 & 0.4062 & 1203 & 489 & 4793 & 10554 & 8.7737 \\
45 & 0.1115 & 714 & 80 & 3372 & 5761 & 8.0653 \\
50 & 0.4945 & 635 & 314 & 2389 & 2389 & 3.7637 \\
& & 321 & & & &
\end{tabular}

GROSS NUPTIALITY TABLES FOR FEMALE SINGLES IN SOUTH-SOUTH ZONE

\begin{tabular}{rlrrrrr}
\multicolumn{7}{c}{ Table 3 } \\
\hline \multicolumn{1}{c}{$\mathrm{X}$} & ${ }_{\mathrm{n}} \mathrm{n}_{\mathrm{x}}$ & \multicolumn{1}{c}{$\mathrm{Sx}$} & \multicolumn{1}{c}{$\mathrm{Hx}$} & \multicolumn{1}{c}{$\mathrm{nLx}$} & \multicolumn{1}{c}{$\mathrm{Tx}$} & $e_{x}^{0}$ \\
\hline 10 & 0.3085 & 100000 & 30850 & 422875 & 821615 & 8.2162 \\
15 & 0.6239 & 69150 & 43143 & 237893 & 398740 & 5.7663 \\
20 & 0.5400 & 26007 & 14044 & 94927 & 160847 & 6.1847 \\
25 & 0.6708 & 11963 & 8025 & 39754 & 65920 & 5.5102 \\
30 & 0.6195 & 3938 & 2440 & 13592 & 26166 & 6.6439 \\
35 & 0.4578 & 1499 & 686 & 5778 & 12574 & 8.3906 \\
40 & 0.4233 & 813 & 344 & 3203 & 6796 & 8.3642 \\
45 & 0.1849 & 469 & 87 & 2126 & 3593 & 7.6685 \\
50 & 0.4636 & 382 & 177 & 1467 & 1467 & 3.8410
\end{tabular}


Table 4

EDO

\begin{tabular}{rrrrrrr}
\hline \hline $\mathrm{X}$ & ${ }_{\mathrm{n}} \mathrm{n}_{\mathrm{x}}$ & \multicolumn{1}{c}{$\mathrm{Sx}$} & \multicolumn{1}{c}{$\mathrm{Hx}$} & \multicolumn{1}{c}{$\mathrm{nLx}$} & \multicolumn{1}{c}{$\mathrm{Tx}$} & \multicolumn{1}{c}{$e_{x}^{0}$} \\
\hline 10 & 0.2940 & 100000 & 29400 & 426500 & 811421 & 8.1142 \\
15 & 0.5757 & 70600 & 40644 & 251389 & 384921 & 5.4521 \\
20 & 0.7223 & 29956 & 21637 & 95686 & 133532 & 4.4577 \\
25 & 0.7745 & 8319 & 6443 & 25486 & 37846 & 4.5495 \\
30 & 0.6337 & 1876 & 1189 & 6407 & 12360 & 6.5889 \\
35 & 0.4801 & 687 & 330 & 2611 & 5952 & 8.6627 \\
40 & 0.3476 & 357 & 124 & 1476 & 3341 & 9.3537 \\
45 & 0.1421 & 233 & 33 & 1083 & 1866 & 8.0054 \\
50 & 0.4331 & 200 & 87 & 783 & 783 & 3.9172 \\
& & 113 & & & &
\end{tabular}

GROSS NUPTIALITY TABLES FOR FEMALE SINGLES IN SOUTH-WEST ZONE

Table 5 OSUN

\begin{tabular}{ccrrrrr}
\hline \hline $\mathrm{X}$ & $\mathrm{n}_{\mathrm{x}}$ & \multicolumn{1}{c}{$\mathrm{Sx}$} & $\mathrm{Hx}$ & \multicolumn{1}{c}{$\mathrm{nLx}$} & \multicolumn{1}{c}{$\mathrm{Tx}$} & $e_{x}^{0}$ \\
\hline 10 & 0.2795 & 100000 & 27950 & 430125 & 831245 & 8.3125 \\
15 & 0.5667 & 72050 & 40831 & 258173 & 401120 & 5.5672 \\
20 & 0.6907 & 31219 & 21563 & 102188 & 142947 & 4.5788 \\
25 & 0.7897 & 9656 & 7625 & 29217 & 40758 & 4.2210 \\
30 & 0.7423 & 2031 & 1507 & 6385 & 11541 & 5.6835 \\
35 & 0.3067 & 523 & 160 & 2215 & 5156 & 9.8535 \\
40 & 0.4299 & 363 & 156 & 1424 & 2941 & 8.1065 \\
45 & 0.3407 & 207 & 70 & 858 & 1517 & 7.3343 \\
50 & 0.0670 & 136 & 9 & 659 & 659 & 4.8325 \\
& & 127 & & & &
\end{tabular}

Table 6

ONDO

\begin{tabular}{ccrrrrr}
\hline \hline $\mathrm{X}$ & ${ }_{\mathrm{n}} \mathrm{n}_{\mathrm{x}}$ & \multicolumn{1}{c}{$\mathrm{Sx}$} & \multicolumn{1}{c}{$\mathrm{Hx}$} & \multicolumn{1}{c}{$\mathrm{nLx}$} & \multicolumn{1}{c}{$\mathrm{Tx}$} & $e_{x}^{0}$ \\
\hline 10 & 0.2486 & 100000 & 24860 & 437850 & 944338 & 9.4434 \\
15 & 0.4680 & 75140 & 35166 & 287786 & 506488 & 6.7406 \\
20 & 0.5888 & 39974 & 23537 & 141030 & 218701 & 5.4710 \\
25 & 0.7303 & 16438 & 12004 & 52177 & 77671 & 4.7253 \\
30 & 0.7216 & 4433 & 3199 & 14168 & 25495 & 5.7508 \\
35 & 0.3502 & 1234 & 432 & 5090 & 11326 & 9.1769 \\
40 & 0.4932 & 802 & 396 & 3021 & 6236 & 7.7753 \\
45 & 0.1848 & 406 & 75 & 1844 & 3215 & 7.9091 \\
50 & 0.3459 & 331 & 115 & 1370 & 1370 & 4.1352 \\
& & 217 & & & &
\end{tabular}

GROSS NUPTIALITY TABLES FOR FEMALE SINGLES IN NORTH-CENTRAL ZONE

\begin{tabular}{ccrrrrr} 
Table 7 & \multicolumn{7}{c}{ BENUE } \\
\hline \hline $\mathrm{X}$ & ${ }_{\mathrm{n}} \mathrm{n}_{\mathrm{x}}$ & \multicolumn{1}{c}{$\mathrm{Sx}$} & \multicolumn{1}{c}{$\mathrm{Hx}$} & \multicolumn{1}{c}{$\mathrm{nLx}$} & \multicolumn{1}{c}{$\mathrm{Tx}$} & \multicolumn{1}{c}{$e_{x}^{0}$} \\
\hline 10 & 0.5115 & 100000 & 51150 & 372125 & 608554 & 6.0855 \\
15 & 0.7339 & 48850 & 35851 & 154622 & 236429 & 4.8399 \\
20 & 0.6140 & 12999 & 7981 & 45041 & 81806 & 6.2933 \\
25 & 0.6208 & 5018 & 3115 & 17301 & 36765 & 7.3272 \\
30 & 0.4928 & 1903 & 938 & 7169 & 19464 & 10.2298 \\
35 & 0.1168 & 965 & 113 & 4543 & 12295 & 12.7402 \\
40 & 0.3350 & 852 & 286 & 3548 & 7751 & 9.0945 \\
45 & 0.2309 & 567 & 131 & 2507 & 4204 & 7.4165 \\
50 & 0.4430 & 436 & 193 & 1697 & 1697 & 3.8925 \\
& & 243 & & & &
\end{tabular}




\begin{tabular}{ccrrrrr} 
Table 8 & \multicolumn{7}{c}{ NIGER } \\
\hline \hline $\mathrm{X}$ & $\mathrm{n} \mathrm{n}_{\mathrm{x}}$ & \multicolumn{1}{c}{$\mathrm{Sx}$} & \multicolumn{1}{c}{$\mathrm{Hx}$} & \multicolumn{1}{c}{$\mathrm{nLx}$} & \multicolumn{1}{c}{$\mathrm{Tx}$} & \multicolumn{1}{c}{$e_{x}^{0}$} \\
\hline 10 & 0.4795 & 100000 & 47950 & 380125 & 640270 & 6.4027 \\
15 & 0.6950 & 52050 & 36175 & 169813 & 260145 & 4.9980 \\
20 & 0.6439 & 15875 & 10222 & 53821 & 90332 & 5.6901 \\
25 & 0.6559 & 5653 & 3708 & 18996 & 36511 & 6.4584 \\
30 & 0.5477 & 1945 & 1065 & 7063 & 17515 & 9.0037 \\
35 & 0.1782 & 880 & 157 & 4007 & 10452 & 11.8793 \\
40 & 0.3974 & 723 & 287 & 2897 & 6445 & 8.9131 \\
45 & 0.1392 & 436 & 61 & 2027 & 3548 & 8.1423 \\
50 & 0.3781 & 375 & 142 & 1521 & 1521 & 4.0548 \\
& & 233 & & & &
\end{tabular}

GROSS NUPTIALITY TABLES FOR FEMALE SINGLES IN NORTH-WEST ZONE Table 9 KANO

\begin{tabular}{rrrrrrr}
\hline \hline $\mathrm{X}$ & $\mathrm{n}_{\mathrm{x}}$ & \multicolumn{1}{c}{$\mathrm{Sx}$} & \multicolumn{1}{c}{$\mathrm{Hx}$} & \multicolumn{1}{c}{$\mathrm{nLx}$} & \multicolumn{1}{c}{$\mathrm{Tx}$} & \multicolumn{1}{c}{$e_{x}^{0}$} \\
\hline 10 & 0.6784 & 100000 & 67840 & 330400 & 501491 & 5.0149 \\
15 & 0.6999 & 32160 & 22509 & 104528 & 171091 & 5.3200 \\
20 & 0.5877 & 9651 & 5672 & 34076 & 66563 & 6.8968 \\
25 & 0.5934 & 3979 & 2361 & 13993 & 32487 & 8.1641 \\
30 & 0.4660 & 1618 & 754 & 6205 & 18494 & 11.4304 \\
35 & 0.2200 & 864 & 190 & 3845 & 12289 & 14.2236 \\
40 & 0.1210 & 674 & 82 & 3166 & 8444 & 12.5302 \\
45 & 0.0759 & 592 & 45 & 2849 & 5279 & 8.9109 \\
50 & 0.2250 & 547 & 123 & 2429 & 2429 & 4.4375 \\
& & 424 & & & &
\end{tabular}

Table 10 SOKOTO

\begin{tabular}{rrrrrrr}
\hline \hline $\mathrm{X}$ & ${ }_{\mathrm{n}} \mathrm{n}_{\mathrm{x}}$ & \multicolumn{1}{c}{$\mathrm{Sx}$} & \multicolumn{1}{c}{$\mathrm{Hx}$} & \multicolumn{1}{c}{$\mathrm{nLx}$} & \multicolumn{1}{c}{$\mathrm{Tx}$} & \multicolumn{1}{c}{$e_{x}^{0}$} \\
\hline 10 & 0.7198 & 100000 & 71980 & 320050 & 479578 & 4.7958 \\
15 & 0.7144 & 28020 & 20017 & 90056 & 159528 & 5.6934 \\
20 & 0.5214 & 8003 & 4173 & 29581 & 69471 & 8.6812 \\
25 & 0.4969 & 3830 & 1903 & 14392 & 39890 & 10.4152 \\
30 & 0.3823 & 1927 & 737 & 7793 & 25498 & 13.2328 \\
35 & 0.1736 & 1190 & 207 & 5435 & 17705 & 14.8755 \\
40 & 0.0746 & 984 & 73 & 4735 & 12271 & 12.4752 \\
45 & 0.1883 & 910 & 171 & 4123 & 7536 & 8.2793 \\
50 & 0.1520 & 739 & 112 & 3413 & 3413 & 4.6200 \\
& & 627 & & & &
\end{tabular}

GROSS NUPTIALITY TABLES FOR FEMALE SINGLES IN NORTH-EAST ZONE

Table 11

BAUCHI

\begin{tabular}{ccrrrrr}
\hline \hline $\mathrm{X}$ & ${ }_{\mathrm{n}} \mathrm{n}_{\mathrm{x}}$ & \multicolumn{1}{c}{$\mathrm{Sx}$} & $\mathrm{Hx}$ & $\mathrm{nLx}$ & \multicolumn{1}{c}{$\mathrm{Tx}$} & \multicolumn{1}{c}{$e_{x}^{0}$} \\
\hline 10 & 0.6671 & 100000 & 66710 & 333225 & 507687 & 5.0769 \\
15 & 0.6894 & 33290 & 22950 & 109075 & 174462 & 5.2407 \\
20 & 0.6015 & 10340 & 6219 & 36151 & 65387 & 6.3238 \\
25 & 0.5960 & 4120 & 2456 & 14463 & 29236 & 7.0954 \\
30 & 0.5805 & 1665 & 966 & 5907 & 14774 & 8.8748 \\
35 & 0.0041 & 698 & 3 & 3484 & 8866 & 12.6962 \\
40 & 0.5128 & 695 & 357 & 2586 & 5382 & 7.7382 \\
45 & 0.1447 & 339 & 49 & 1572 & 2796 & 8.2517 \\
50 & 0.3101 & 290 & 90 & 1224 & 1224 & 4.2248
\end{tabular}




\begin{tabular}{ccrrrrr} 
Table 12 & \multicolumn{7}{c}{ YOBE } \\
\hline \hline $\mathrm{X}$ & ${ }_{\mathrm{n}} \mathrm{n}_{\mathrm{x}}$ & \multicolumn{1}{c}{$\mathrm{Sx}$} & \multicolumn{1}{c}{$\mathrm{Hx}$} & \multicolumn{1}{c}{$\mathrm{nLx}$} & \multicolumn{1}{c}{$\mathrm{Tx}$} & \multicolumn{1}{c}{$e_{x}^{0}$} \\
\hline 10 & 0.6967 & 100000 & 69670 & 325825 & 470357 & 4.7036 \\
15 & 0.7636 & 30330 & 23160 & 93750 & 144532 & 4.7653 \\
20 & 0.5982 & 7170 & 4289 & 25127 & 50782 & 7.0826 \\
25 & 0.5216 & 2881 & 1503 & 10648 & 25655 & 8.9052 \\
30 & 0.4756 & 1378 & 655 & 5252 & 15007 & 10.8888 \\
35 & 0.1169 & 723 & 84 & 3402 & 9755 & 13.4970 \\
40 & 0.2919 & 638 & 186 & 2726 & 6352 & 9.9527 \\
45 & 0.1641 & 452 & 74 & 2074 & 3627 & 8.0249 \\
50 & 0.3562 & 378 & 135 & 1552 & 1552 & 4.1095 \\
& & 243 & & & &
\end{tabular}

where
$\mathrm{X}: \quad$ Age in years
${ }_{n} n_{x}: \quad$ Five-year nuptiality rate
Sx: $\quad$ Number single at age $X$
$\mathrm{Hx}$ : $\quad$ Number of singles marrying at age $X$
Number of single females years lived as never married in the age interval $(x$,
$\mathrm{nLx}: \quad \mathrm{x}+5)$
Tx Total number of years lived as single after age $\mathrm{x}$
$e_{x}^{0}: \quad$ Average number of years of single life remaining to a single female at age $\mathrm{x}$

The following points are highlighted from a critical study of the nuptiality tables:

(i) The constructed gross nuptiality tables for single females show variation from zone to zone which could be a reflection of the social-cultural and heterogeneity of the population. In all the geopolitical zones considered, the proportion of married females rises with age, peaking around age-interval $20-29$, after which there is a gradual decline in the proportion married.

(ii) From the gross nuptiality tables, the three northern zones have relatively high nuptiality rates for single females at age-internal 10-14 years when compared with the three southern zones, but with a sharp decline after age 30 . This is an indication that northern females tend to marry earlier than their counterparts in the southern regions. For single females in the Southeast, Southwest and South-south, the nuptiality rates are initially small, but increase gradually until they reached a maximum at age group 25-29, after which they gradually decline. The nuptiality rates at the age-group 10-14 years are relatively the lowest in Southeastern states, implying a low rate of girl-child marriage in the zone.

(iii) The average expected years of single life to first marriage for single females at different ages $\left(e_{x}^{0}\right)$ as provided in the last column of the gross nuptiality tables revealed that the mean age at marriage was the highest in Southeast, followed by Southwest, South-south, Northcentral, Northeast and Northwest. The low mean age at marriage in the age-group 10-14 among single females in the northern zones could be ascribed to the tradition of early marriage in the zones, particularly in the Northwest zone which has the lowest mean age at marriage, an indication of the highest rate of girl-child marriage in the zone.

(iv) It could be inferred that the mean age at marriage for single females in the age- group $10-14$, as shown in the constructed gross nuptiality tables, for Northeast, Northwest and Northcentral ranges from 14.7 to 16.4 years, and for Southeast, Southwest and South-south mean age at marriage ranges from 18 to 21.7 years. Previous investigation revealed that the mean age at first marriage for single females has increased slightly overtime. (Omu et al, 1986; Kuteyi, 1988; Isiugo-Abanihe et al, 1993). This development might be ascribed to the government policy on educating young females free for primary school education. School enrolment for young females has improved, and education being directly related to age at first marriage has increased with rapid socioeconomic change, (Kuteyi, 1988).

\section{DISSOLUTION OF MARITAL UNION AMONG MARRIED FEMALE NIGERIANS}

Pattern of marital dissolution is one of the basic indicators of a population's social structure. In this segment of the study, the objective is to determine the probabilities of eventual exit from married status due to separation, divorce and widowhood, and to examine the regional differences in rates of marital dissolution of married females. Such differences not only have meaning in the study of fertility but also in the study of sociological and medical problems associated with marital disruption. The differences also have implications on the economic factors, which affect the supply of labour among married women, and the relation of dependency to marital adjustment of the persons or members of the family concerned. Examining the regional differences of the rate of marital dissolution will 
invariably shed light on marital stability of married females across the six geo-political zones.

\subsection{Description of the categories of female marital status}

The data on female marital status, extracted from the 1991 population census data are, classified by age, state and marital status. The data are at age-interval of five years, with age-interval 10-14 as the minimum ageinterval at which marriage could occur for the single females. All female respondents enumerated during the census fell into one of the five categories of marital status: (i) Never married (ii) Married (iii) Separated (iv) Divorced (v) Widowed.

In this section of the study, emphasis is laid on the married, separated, divorced and widowed category of women, in order to analyse the regional differences of marital stability among married females across the six geo-political zones in Nigeria. The descriptions of the categories of marital status of female respondents according to the National Population Commission are highlighted below:

Married: Female respondents categorised as married are those who had a living spouse at the time of the enumeration, irrespective of whether the spouse was at home at the time of interview or away from home. This includes all heterosexual union, but excludes the practices of polyandry, animism and other traditional beliefs.

Separated: Married women in this category are those that had been previously married, but the couple has been separated by judicial, religious or customary processes of law or by mutual agreement of the partners.

Divorced: Divorced status unlike the separated implies the legal, customary, or religious termination of a marital union. Women whose marital unions have been terminated and who are legally free to remarry but have not done so are described as divorced.

Widowed: This category of female respondents is those whose husbands have died and have not subsequently remarried. (National Population Commission, p. 106-107).

\subsection{Multiple decrement table}

Multiple decrement table has found its application in various demographic fields, ranging from the study of pattern of termination of contraceptive to the study of contraceptive effectiveness, (Balakrishnan et al, 1970; Potter, 1963; Freedman et al, 1969). Application of multiple decrement techniques on married female cohort will shed light on the process of transformation from married status to the dissolution of marriage, and thereby gain insight into the regional variations in females' marital stability.
A multiple process is one in which individuals have more than one mode of exit. According to Jordan (1952), a multiple decrement table is a mathematical model which assumes a large body of lives subject to several independent causes of decrement which are operating continuously. The body of lives forms a closed group, there being no new entrants and no re-entrants after the operation of various decrements, (Alistair, 1979). The initials are married women who are exposed to the risks of separation, divorce and widowhood.

\subsection{Functions of multiple decrement nuptiality table}

Construction of multiple decrement nuptiality table is conceptually analogous to the construction of single life table. It is only necessary to add columns equivalent to other columns on the single decrement life table, which pertain exclusively to particular modes of exit from the table. The interpretation of columns in the constructed multiple decrement nuptiality tables are:

${ }_{n} q_{x}^{i}$ : the probability of leaving the married cohort due to cause ' $i$ ' in the age interval $(x, x+n)$, for a woman who reached age $x$.

${ }_{n} d^{i}{ }_{x}$ : number of decrements from cause ' $i$ ' in the age interval $(x, x+n)$

${ }_{n} d_{x}^{t}$ : the total number of decrements from all causes between ages $x$ and $x+n$

$1_{x}$ : number of married female cohort who reached age

$x$. i.e number of persons who survived all causes of decrement from married status before age $x$.

${ }_{n} p_{x}^{t}$ : total probability of remaining in the married cohort in the age interval $(x, x+n)$.

Therefore

$$
\begin{aligned}
& \mathrm{n}_{\mathrm{x}}^{\mathrm{t}}=\sum_{\mathrm{i}=1}^{3} \mathrm{~d}_{\mathrm{x}}^{\mathrm{i}} \\
& ={ }_{\mathrm{n}} \mathrm{d}_{\mathrm{x}}^{1}+{ }_{\mathrm{n}} \mathrm{d}_{\mathrm{x}}^{2}+{ }_{\mathrm{n}} \mathrm{d}_{x}^{3}
\end{aligned}
$$

where

$$
\begin{aligned}
& i=1 \text { implies separation } \\
& i=2 \text { implies divorce } \\
& i=3 \text { implies widowhood }
\end{aligned}
$$

The model is based on the assumption that re-entrants, (re-marriages) is not allowed, therefore

$$
1_{\mathrm{x}+\mathrm{n}}=1_{\mathrm{x}}-{ }_{\mathrm{n}} \mathrm{d}^{1}{ }_{\mathrm{x}}-{ }_{\mathrm{n}} \mathrm{d}_{\mathrm{x}}^{2}-{ }_{\mathrm{n}} d_{x}^{3}
$$

So that

$$
1_{\mathrm{x}+\mathrm{n}}=1_{\mathrm{n}}-\mathrm{d}_{\mathrm{x}}^{\mathrm{t}}
$$

Number of persons reaching age $x$ who will later succumb to cause ' $\mathrm{i}$ ' is

$$
\mathrm{l}_{\mathrm{x}}^{\mathrm{i}}=\sum_{\mathrm{i}=1}^{3}{ }_{\mathrm{n}} \mathrm{d}_{\mathrm{x}}^{\mathrm{i}}
$$

The probability of leaving married status due to cause $i$ is in the age-interval $(x, x+n)$ for a married woman who reached age $\mathrm{x}$ is 


$$
{ }_{n} q_{x}^{i}=\frac{{ }_{n} d_{x}^{i}}{l_{x}},
$$

table (from married status) due to cause 'i' for persons age $x$

And therefore

$$
{ }_{n} q_{x}^{t}=\frac{{ }_{n}^{t}}{1_{x}}=\sum_{i=1}^{3}{ }_{n} q_{x}^{i}
$$

The total probability of remaining in the married cohort in the age-interval

$(x, x+n)$ is therefore

$$
{ }_{\mathrm{n}} \mathrm{p}_{\mathrm{x}}^{\mathrm{t}}=1-{ }_{\mathrm{n}} \mathrm{q}_{x}^{t}
$$

An important function on the multiple decrement table is<smiles>C[Al]1CC[Al]C1</smiles>

which is the probability of eventual exit from the
5.4 Presentation of the constructed multiple decrement nuptiality tables

The constructed multiple decrement nuptiality tables for married females for the twelve states selected across the six geo-political zones in Nigeria are presented in tables 13 to 24 . The selected states are the same states used in the nuptiality tables with, the purpose of making comparison between the gross nuptiality tables and the multiple decrement tables in order to examine the implication of timing of marriage on the marital stability of the married females.

Once the age-specific probabilities of exit from married status for each of the three causes have been obtained, the appropriate tables are not difficult to construct. Interpretation of the various columns in the multiple decrement tables are also given in the footnotes after table 24. 

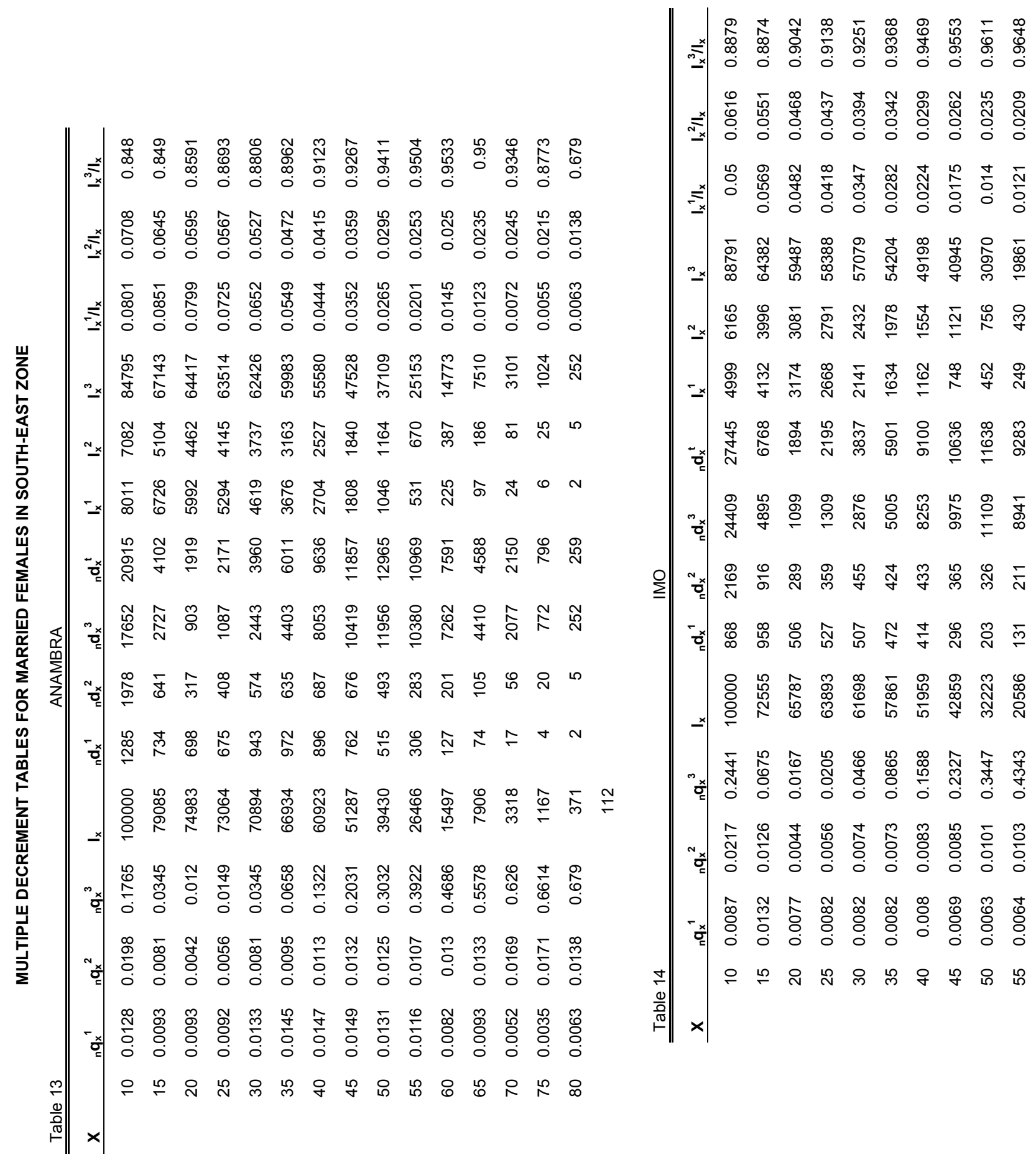


\begin{tabular}{|c|c|c|}
\hline & 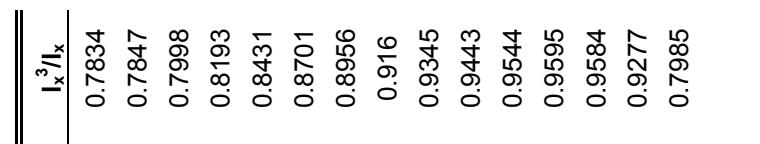 & 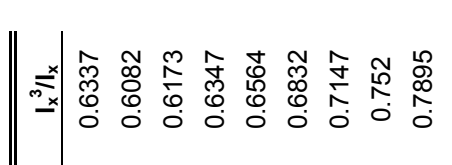 \\
\hline & 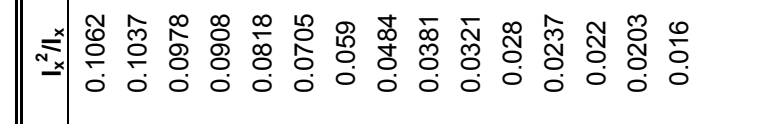 & 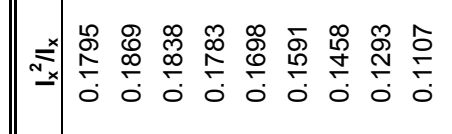 \\
\hline & 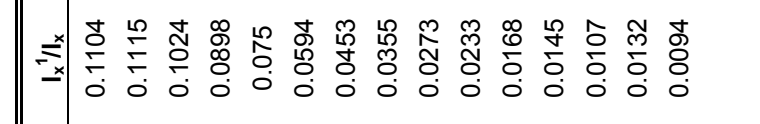 & 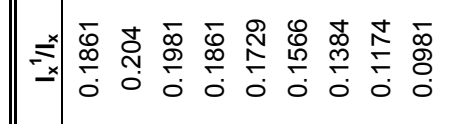 \\
\hline & 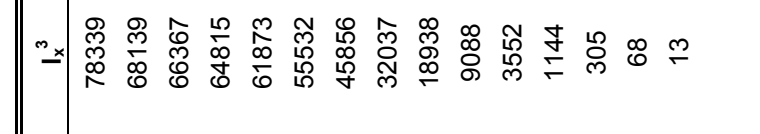 & 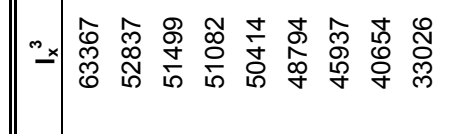 \\
\hline & 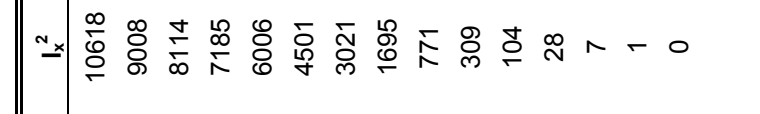 & 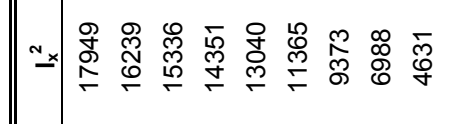 \\
\hline 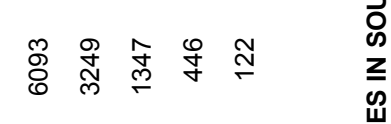 & 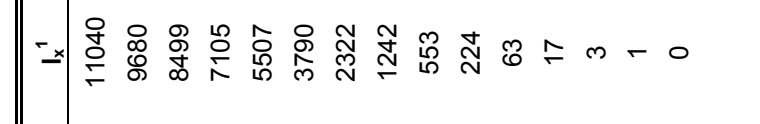 & 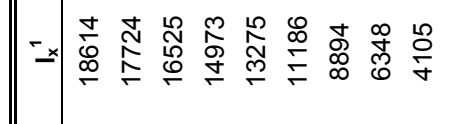 \\
\hline & 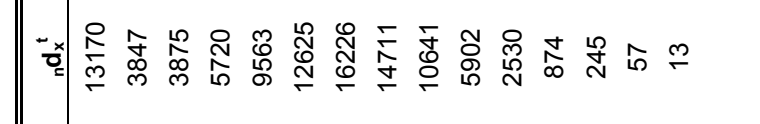 & 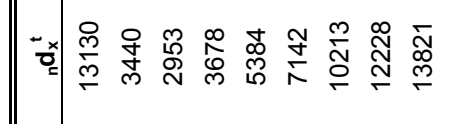 \\
\hline & 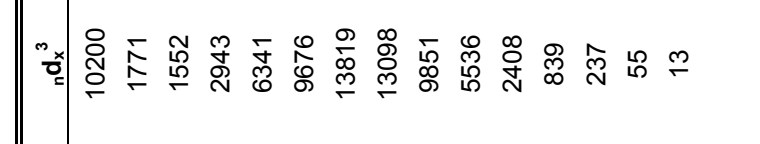 & 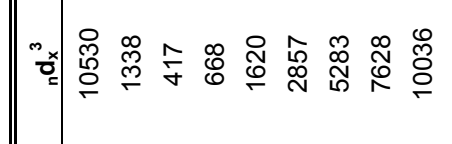 \\
\hline & 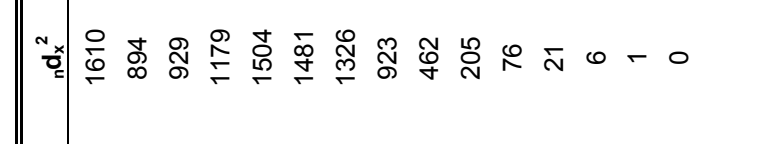 & 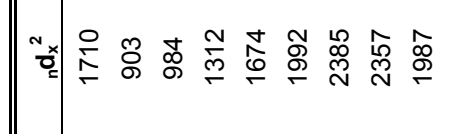 \\
\hline & 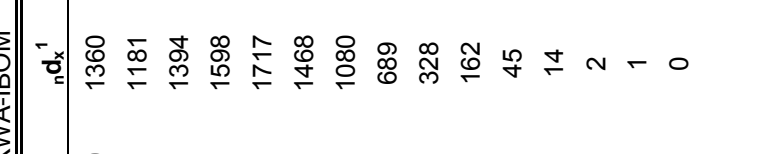 & 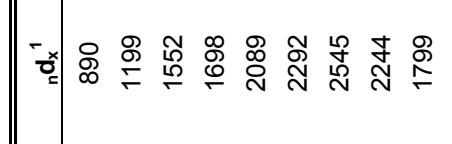 \\
\hline & 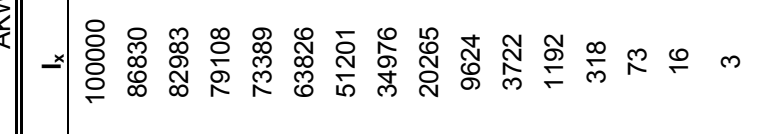 & 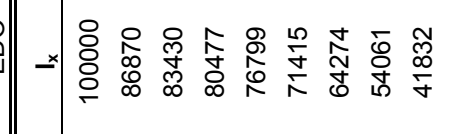 \\
\hline & 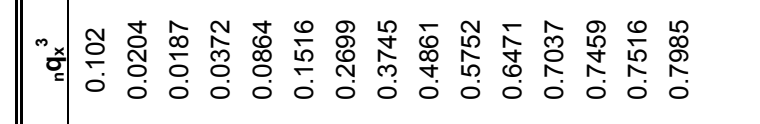 & 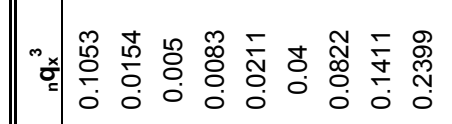 \\
\hline & 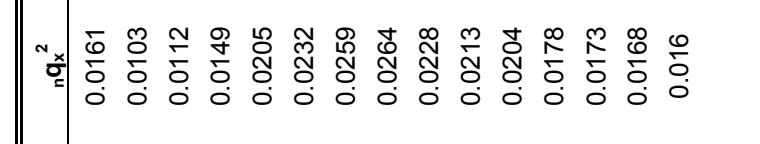 & 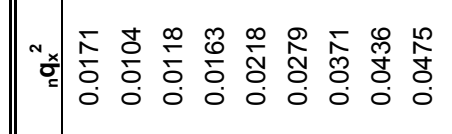 \\
\hline & 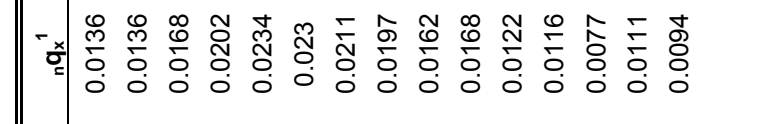 & 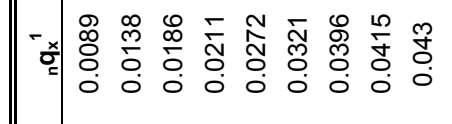 \\
\hline
\end{tabular}




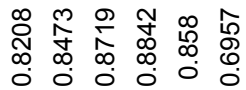

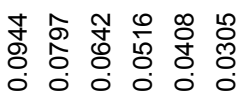

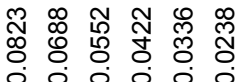

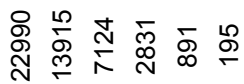

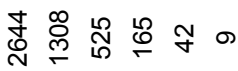

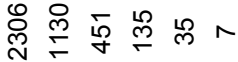

赵

노웡

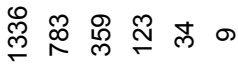

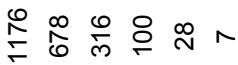

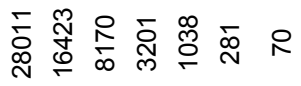

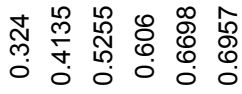

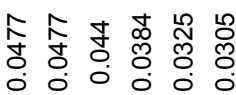

苟

台 8 吕

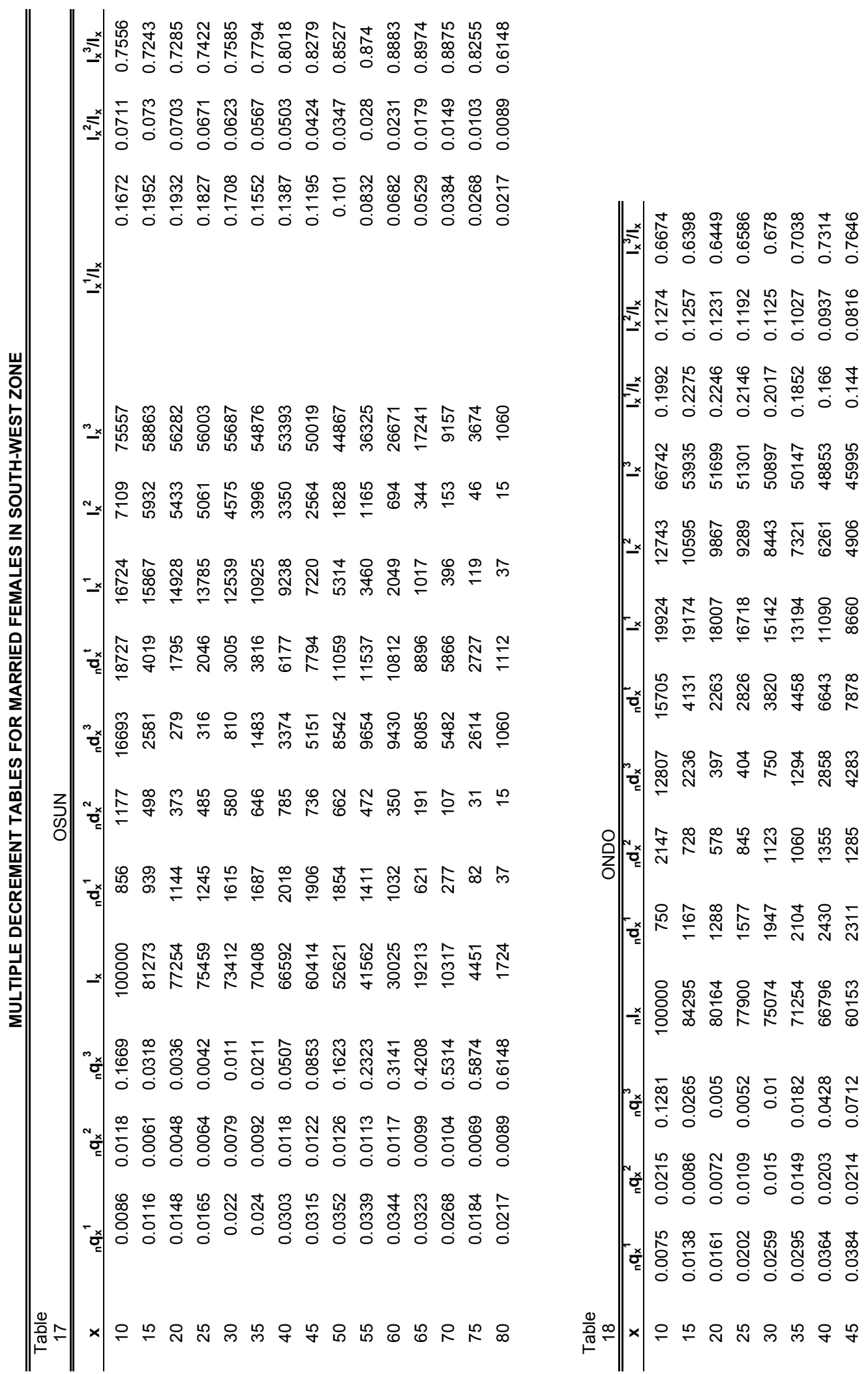




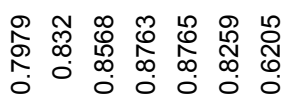

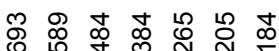

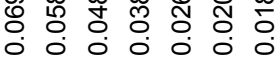

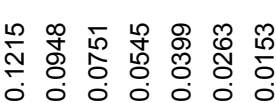

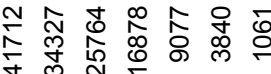

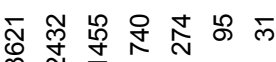

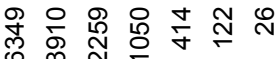

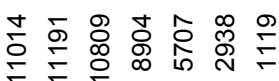

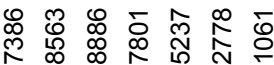
ஐ 원

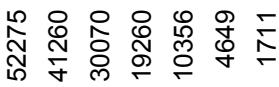

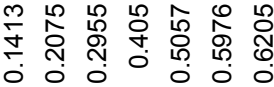
సิ

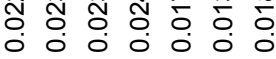

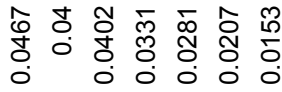
욘요용요용

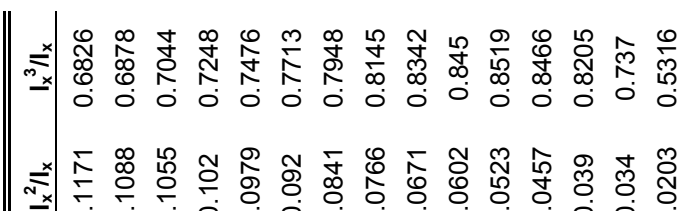

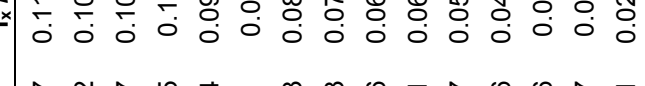

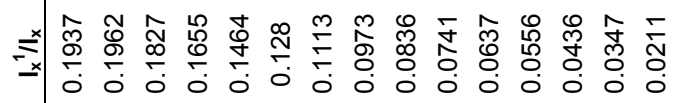

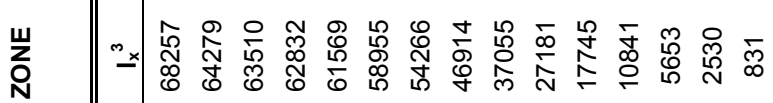

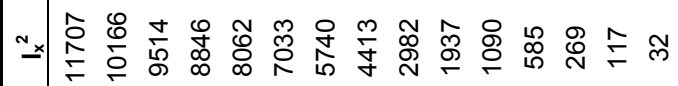

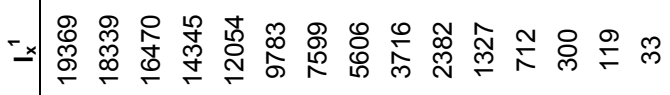

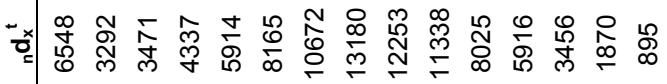

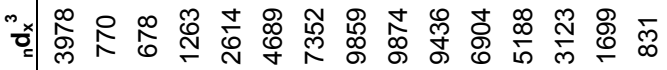

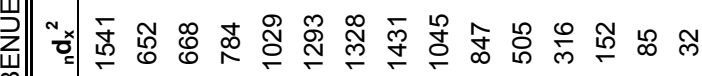

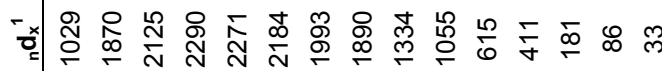

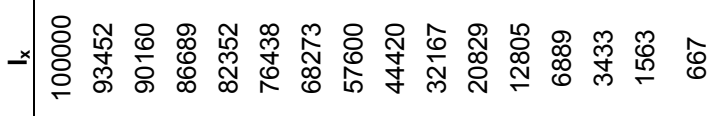

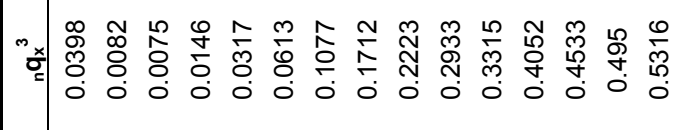

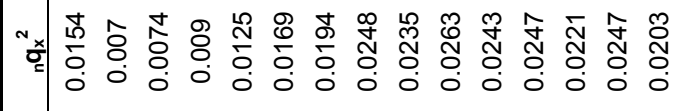

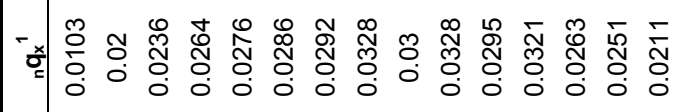

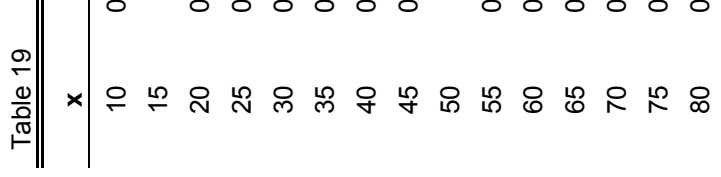

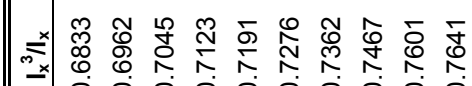

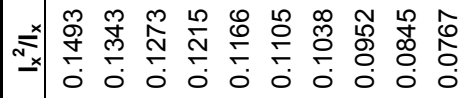

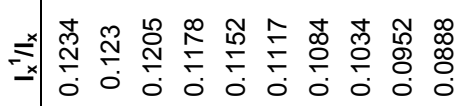

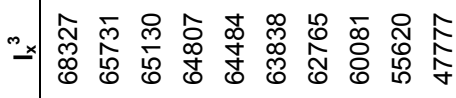

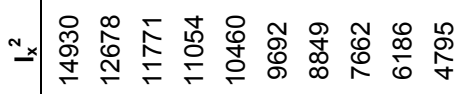

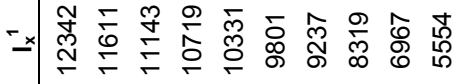

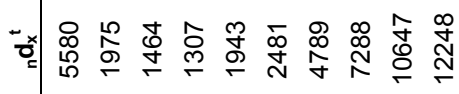

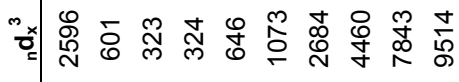

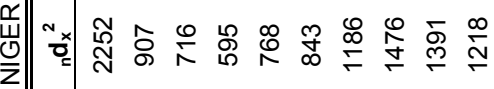

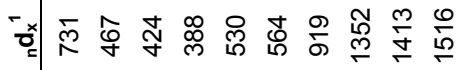

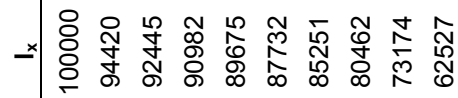

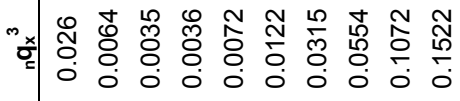

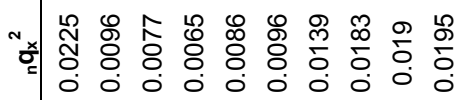

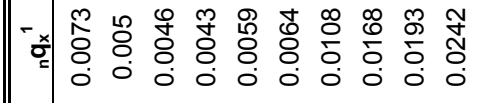

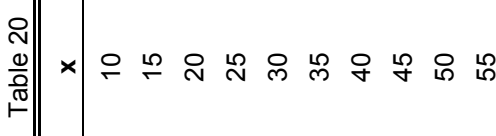




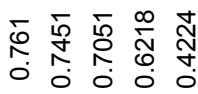

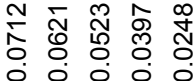

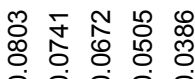

ఝి



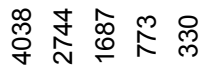

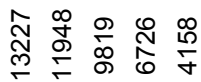

氙

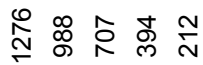

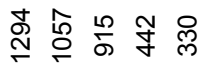

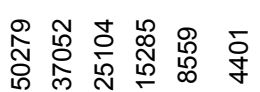

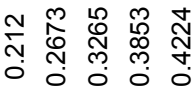

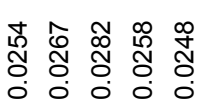

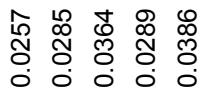

응요용

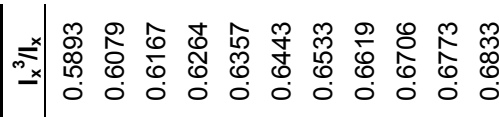

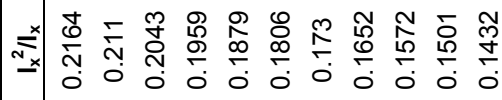

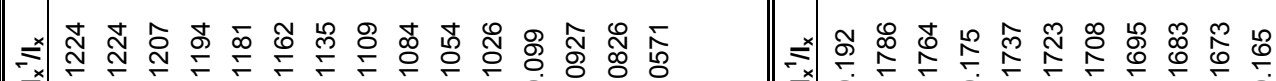

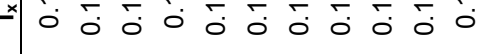

×

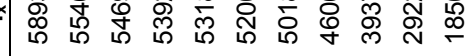

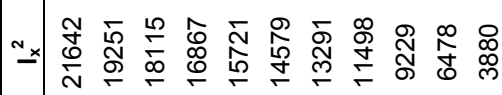

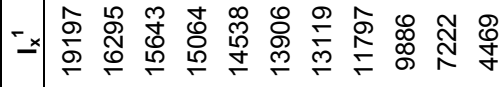

-x.

|

全

-×

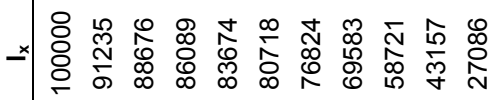

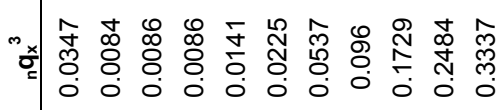

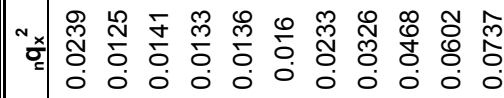

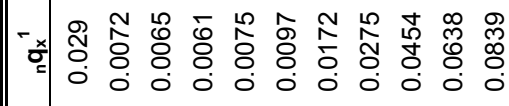

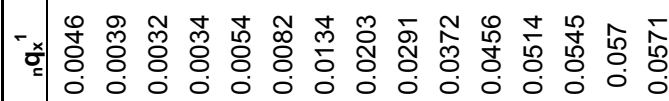

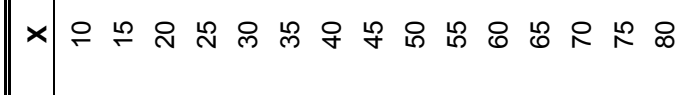

ลิ
$\frac{0}{0}$
$\frac{\pi}{\circ}$ 


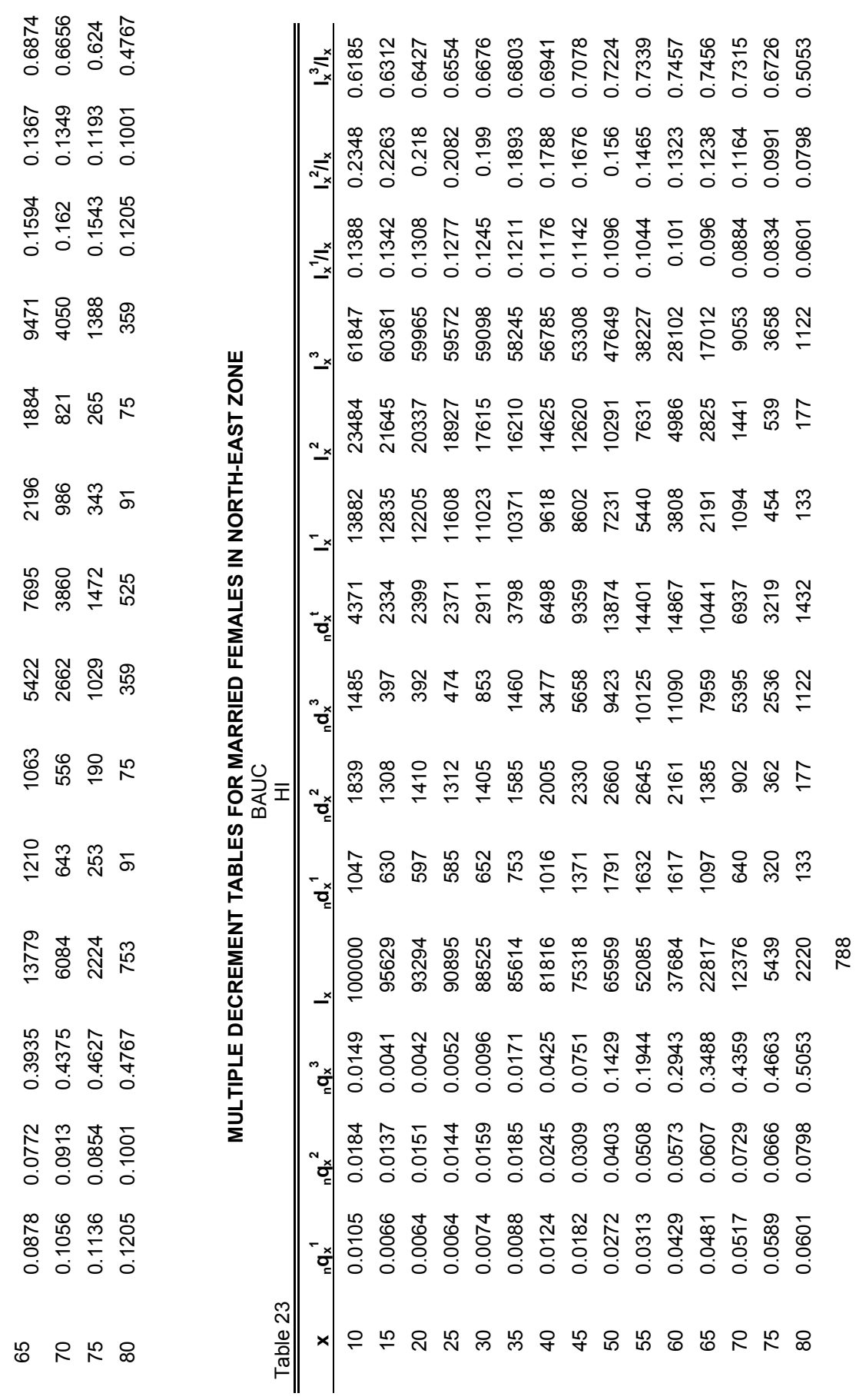

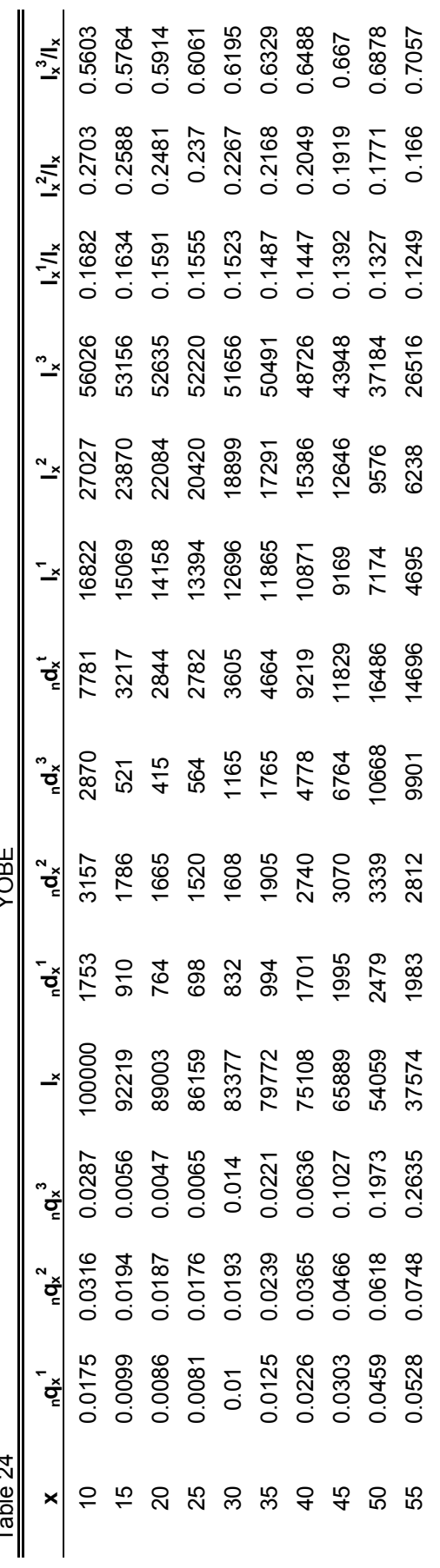




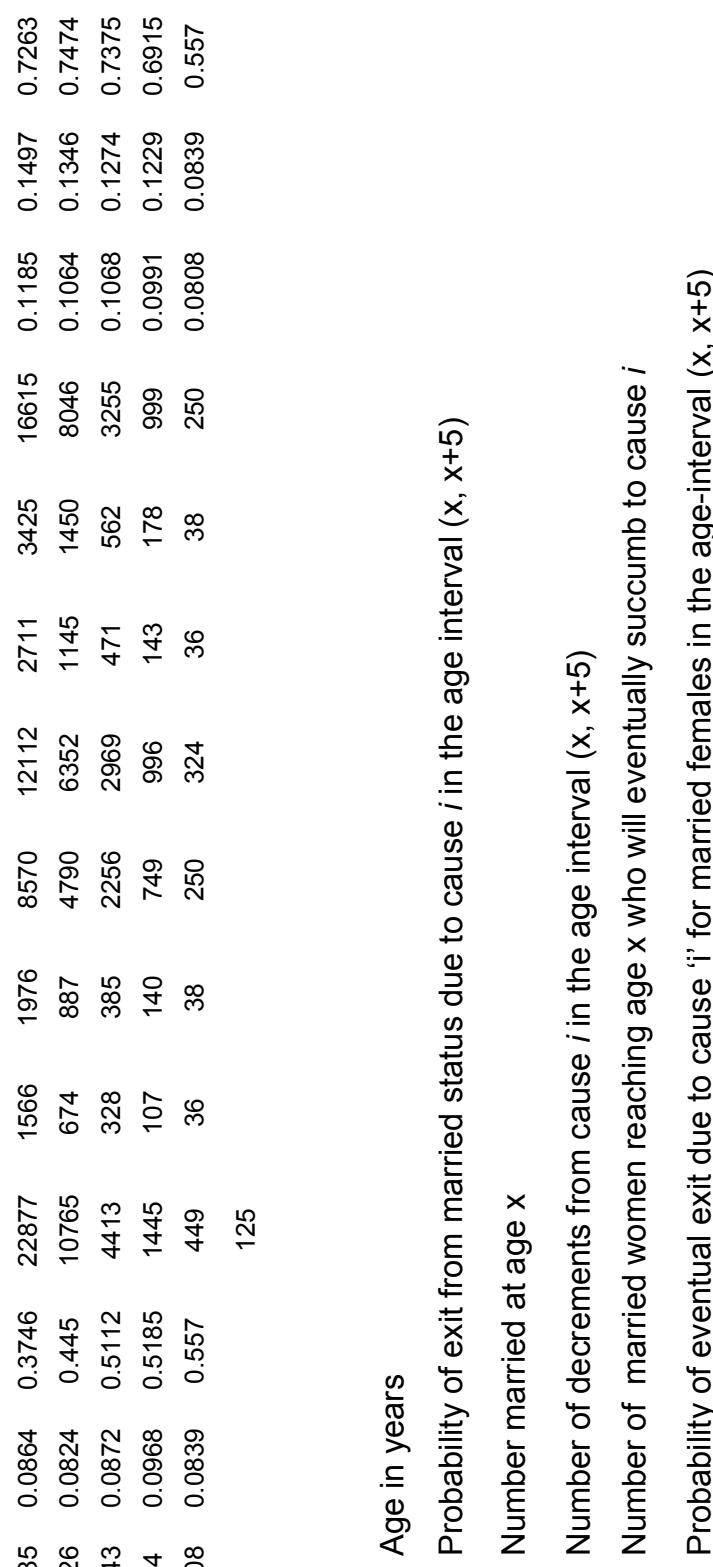

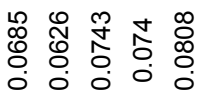

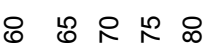

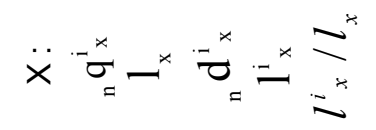

$\frac{0}{\frac{0}{3}}$ 
6. DISCUSSION

(i) A critical study of the multiple decrement nuptiality tables shows that the probabilities of eventual exit from married status due to separation and divorce designated as $1_{x}^{1} / 1_{x}$ and $1_{x}^{2} / 1_{x}$ respectively are initially high in all the states in the six zones, but tend to decline after ageinterval 25-29. This is an indication that marriages become more stable around ageinterval 25-29. Conversely, the probability of eventual exit from married status due to widowhood is initially small, but increases with age until around age 70 after which there is a decline in widowhood. This might be due to the fact that after age 70, greater percentage of married women must have died.

(ii) The rate of marital dissolution due to separation is lowest in Southeast. This might be attributable to the culture of high bride-price in the zone, which makes it difficult for husbands to separate from their wives, since the cost of marrying another wife is expensive.

(iii) The probability of exit from married status due to divorce is the highest in Northeast followed by Northwest, Northcentral, South-south, Southwest, and is the lowest in Southeast. This suggests that marriages are more stable in Southeast compared to other zones. The high rate of divorce in the three northern zones might be due to the culture of child marriage that is prevalent in the zones, since most adolescent married females could be physiologically and psychologically immature to manage marital challenges. Previous scientific investigations on this issue show that early marriage is associated with marital disruption, (Isiugo-Abanihe et al, 1993).

(iv) Generally, the probability of exit due to widowhood is the highest among the three causes of marital dissolution. Particularly, it is the highest in Southeast, and is the lowest in Northeast. It can therefore, be inferred that married females in Southeast have the highest tendency of early widowhood compared with other zones. This might be attributable to the wide age-gap that usually exists between married couples in Southeast.

(v) From the multiple decrement nuptiality tables, the summary of the probability of eventual exit from married status due to the three modes of decrement considered, and the nuptiality rates at ageinterval 10-14 extracted from the constructed gross nuptiality tables are shown in table 25 . Table 25 shows that zones with highest nuptiality rates at ageinterval 10-14, particularly Northeast and Northwest have highest risk of marital dissolution through divorce, while the rate of marital dissolution due to separation is generally high in all the zones at ageinterval 10- 14, except in Southeast zone which exhibit low rate of separation at that age-interval. Incidence of widowhood is the highest in Southeast and South-south, though having the lowest nuptiality rate at age-interval 10-14. The probabilities of eventual exit due to each of the three modes of decrement for the twelve selected states across the six zones are graphically portrayed in Figures 1 to 3, for an easy comparison at a glance.

Table 25: Probabilities of eventual exit and nuptiality rates at age-interval 10-14 for the selected states in the six geopolitical zones.

\begin{tabular}{|l|l|l|l|l|l|}
\hline $\begin{array}{l}\text { Geo-political } \\
\text { zones }\end{array}$ & $\begin{array}{l}\text { Selected } \\
\text { states }\end{array}$ & $\begin{array}{l}\text { Separation } \\
l_{x}^{1}\end{array}$ & $\begin{array}{l}\text { Divorce } \\
l_{x}^{2}\end{array}$ & $\begin{array}{l}\text { Widowhood } \\
l_{x}^{3} / l_{x}\end{array}$ & $\begin{array}{l}\text { Nuptiality rate at age-interval } \\
10-14\left({ }_{5} \mathrm{n}_{\mathrm{X}}\right)\end{array}$ \\
\hline Northeast & Bauchi & 0.1388 & 0.2348 & 0.6185 & 0.6671 \\
\hline & Yobe & 0.1682 & 0.2703 & 0.5603 & 0.6967 \\
\hline Northwest & Sokoto & 0.1224 & 0.1790 & 0.6904 & 0.7198 \\
\hline & Kano & 0.1920 & 0.2164 & 0.5893 & 0.6784 \\
\hline Northcental & Benue & 0.1937 & 0.1171 & 0.6826 & 0.5115 \\
\hline & Niger & 0.1234 & 0.1493 & 0.6833 & 0.4795 \\
\hline Southeast & Anambra & 0.0801 & 0.0708 & 0.8480 & 0.1460 \\
\hline & Imo & 0.0500 & 0.0616 & 0.8879 & 0.1314 \\
\hline Southwest & Ondo & 0.1992 & 0.1274 & 0.6674 & 0.2486 \\
\hline & Osun & 0.1672 & 0.0711 & 0.7556 & 0.2795 \\
\hline South-south & $\begin{array}{l}\text { Akwa- } \\
\text { Ibom }\end{array}$ & 0.1110 & 0.1067 & 0.7822 & 0.3085 \\
\hline & Edo & 0.1861 & 0.1795 & 0.6337 & 0.2940 \\
\hline
\end{tabular}



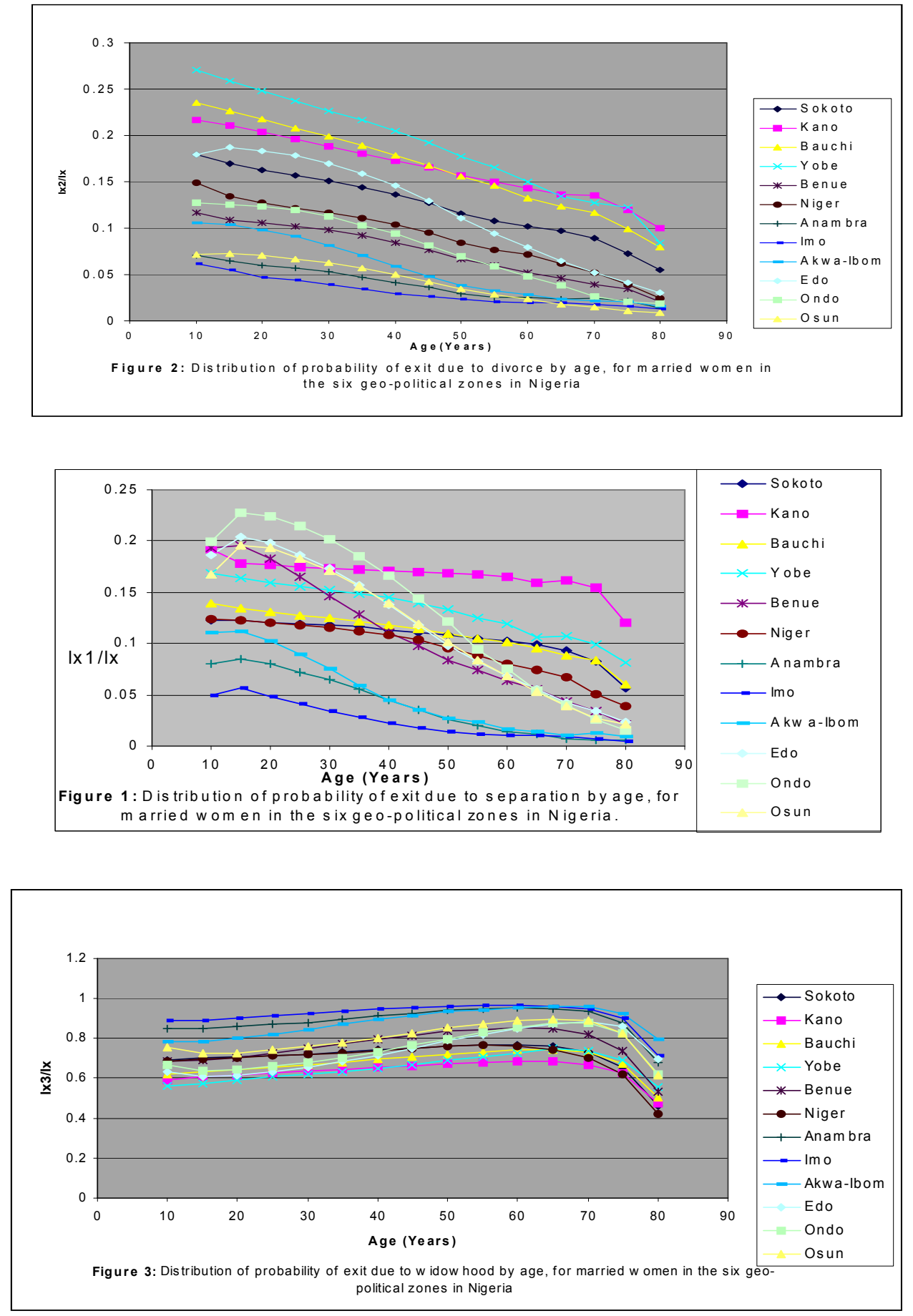

Figure 1 shows the graphical regional variation in the rate of marital termination due to separation, by age for married females in the selected states in the six geopolitical zones. Rate of marital disruption due to separation is high at lower age-interval, but start to decline around age 25. It could be inferred from figure 2 that married females in Northeast have the highest rate of divorce, while figure 3 shows that married women in Southeast have the highest rate of widowhood.

\section{CONCLUSIONS AND RECOMMENDATIONS}

It is evident from the analysis that marriages become more stable as married females advance in age, with zones with high rate of girl-child marriage experiencing high rate of marital instability. Early marriage constitutes a limitation to the educational and employment opportunities of girl-child, and also exposes them to dangerous health risks. Since formal education influences age-at-first marriage and first child birth, a program to encourage young girls to continue formal and informal education is a necessary measure to ensure that young females are profitably occupied before reaching marriageable age. A direct government intervention of an effective legal and policy proposals to legislate a minimum marriage age, free education for females at both primary and secondary school level, therefore is necessary to discourage girl-child marriage. Hopefully, such policy will help in slowing down the high 
rate of population growth, and in reducing the incidence of maternal morbidity and mortality that tends to accompany adolescent childbearing, and in discouraging girl-child marriage.

A relationship between broken homes and moral decadence among youths is a straightforward one. It is therefore, advisable that government should establish more effective marriage counseling units across the nation, with the aim of helping married couples manage their differences. This should help in reducing the high rate of marital dissolution, thereby reducing rate of juvenile delinquency in the society, and in the nation at large.

As much as child marriage has a negative impact on females marital stability, so also is later marriage or marriage delays in Southeast which is usually associated with fatal complications of pregnancy and childbirth that normally characterised advanced age pregnancy. The unfavourable culture of high bridewealth usually demanded from prospective husbands by the brides' family in Southeast should therefore be discouraged. This should encourage men to marry when attaining marriageable age, with an overall effect of removing the wide age-gap that usually exists between couple, which invariably will solve the problem of early widowhood among married females in Southeast.

From this study, it is noticeable that regions where girl-child marriage is prevalent have high rates of marital dissolution due to divorce, and later marriage has a high rate of marital termination through widowhood. To a great extent, adolescent marriage as well as marriage delay has negative implications on marital stability. Appropriate policy should therefore be enforced to discourage girl-child marriage and later marriage of females in order to ensure that Nigerian females marry at the right marriageable age.

Lack of explicit information on the type of marriage, whether polygamy or monogamy, and absence of information on marital mobility of female population, and number of times married, have constituted limitations to this study, which constrained further demographic analysis on the data. The analysts hereby recommend that subsequent population census should include information on types of marriage and marital mobility of married females in order to facilitate further research on marital mobility of married female Nigerians.

\section{REFERENCES}

Aborampah, O. 1987. Plural marriage and fertility differentials: a study of the Yoruba of western Nigeria. Human Organization 46(1): 2938.

Alabi, E.M. 1990. Cultural practices in Nigeria. InterAfrican committee on traditional practices affecting the health of women and children Newsletter (9): 6-7.

Alistair, N. 1979. Life contigencies. London: Williams Heinemann Ltd.

Ampofo, E.K., Omotara, B.A., Otu, T., and Uchnebo, G. 1990. Risk factors of vesico-vaginal fistulae in
Maiduguri, Nigeria: a case-control study. TROPICAL DOCTOR 20(3): 138-139.

Balakrishnari, I. R., Allingham, J.D and Kantner, J.F. 1970. Analysis of oral contraceptive use through multiple decrement life-table techniques. Demography 17:459-465.

Cochrane, S.H., and Farid, S. 1990. Socioeconomic differentials in fertility and their explanation. Population growth and reproduction in SubSaharan Africa: technical analyses of fertility and its consequences: 144-154.

Ephraim R. T. 1999. Nuptiality, early marriage, determinants and consequences: Analysis of Zimbabwe's demographic health and intercentral survey. Proceedings of the $6^{\text {th }}$ scientific workshop of the sub-saharan Africa Network (SUSAN) of the International Biometric Society (IBS): 35-41.

Freedman, R., and Takeshita J. Y. 1969. Family planning in Taiwan. Princeton, New- Jersey: Princeton University Press.

Hajnal, J. 1953. Age at marriage and proportions marrying. Population Studies 7(2): 111-136.

Islam, M.N., and Ahmed A.U. 1998. Age at first marriage and its determinants in Bangladesh. AsiaPacific Population Journal 13(2): 1-17.

Isiugo-Abanihe, U.C. 1995. Briedwealth, marriage and fertility in the east-central states of Nigeria. GENUS 51(3/4):151-178.

Isiugo-Abanihe, U.C., Ebigbola, J.A., Adewuyi, A.A. 1993. Urban nuptiality patterns and marital fertility in Nigeria. Journal of Biosocial Sciences 25(4): 483-498.

Isiugo-Abanihe, U.C. 1987. High bridewealth and age at marriage in Igboland. Proceedings of the Ife conference: 1-15.

Jones, G., and Parker, M. 1967. Use of oral contraceptives: with special reference to developing countries. Studies in Family Planning 24: 1-13.

Jain, A.K. 1969. Fecundability in relation to age in a sample of Taiwanese women. Population Studies 23: 69-85.

Jordan, C. W. 1952. Life contingencies. Chicago: Society of Actuaries.

Kamara, S. D. 1991. Changing roles? African women at the turn of the century. WEST AFRICA March 18: 403 .

Kuteyi, O.E. 1988. National policy on population for Nigeria: an overview. Proceedings of the national orientation seminar on population for states, Population Education Committee: 37-42. 
Malaker, C. R. 1973. Construction of nuptiality tables for the single population in India: 1901-1931. Demography 10(4): 525-535.

Mertens, W. 1965. Methodological aspects of the construction of nuptiality tables. Demography 2:317-338.

National Population Commission. 1998. 1991 Population census of the federal republic on Nigeria: Analytical report at the national level. Nigeria: National Population Commission.

Naushin, I., and Mohammed, A. 1975. Marriage patterns in Pakistan through net nuptiality tables - 1968 and1971. The Pakistan Development Review 14: $207-232$.

Obi, S.N., Ozuma, B.C., and Onyebuchi, A.K. 2002. Pregnancy in unmarried adolescents in Nigeria. International Journal of Gynecology and Obstetrics 77(2): 157-159.

Odujinrin, M. 1995. Marital disruption: welfare of the children thereafter in Nigeria. CHILD ABUSE AND NEGLECT 19(10): 1233-1244.

Olusanya, P. O. 1982. Pattern of nuptiality in Nigeria. Journal of the Nigerian Institute of Social and Economic Research 2(2): 152 -184.

Omideyi, A. K. 1986. Trends in nuptiality patterns of women in Nigeria. GENUS 42(1/2): 113-123.

Omu, A.E. and Uniigbe, J. A. 1986. Acceptance of contraceptive practice by grandmult- iparae in
Benin city, Nigeria. International Journal of Gynaecology and Obsterics 24(2): 145-150.

Potter, R. G. 1963. Additional measure of use effectiveness of contraceptive. Milbank Memorial Fund Quarterly 41: 400-418.

Rehan, N.1984. Knowledge attitude and practice of family planning in Hausa women. Social Science and Medicine 18(10): 839-844.

Schoen, R., and Nelson, V.E. 1974. Marriage, divorce and mortality: a life-table analysis. Demography 11(2): 267-290.

Shryock, H.S., Siegel, J.S. and Associates. 1976. The methods and materials of Demography. (Condensed Ed.). New-York: Academic Press, Inc.

Solvetti, L.M. 1994. Family, marriage and divorce in a Hausa community: a sociological model. AFRICA 64(2):252-271.

Wall, L.L. 1998. Dead mothers and injured wives: the social context of maternal morbidity and mortality among the Hausa of northern Nigeria. STUDIES IN FAMILY PLANNING 29(4): 341359.

Weiss, E., Ayeni, O., Ladipo, O.A., and Otolorin, E.O. 1985. Fertility and modern family planning in rural southwestern Nigeria. Proceedings of conference on the Oyo State CBD project: Community-based delivery of health and family planning services.: 142-148. 